\title{
THE EVOLUTION OF ELECTRONIC ADMINISTRATION AND ITS PRACTICE IN JUDICIAL PROCEEDINGS
}

Summary: $\quad$ The aim of the paper is to examine the provisions on electronic administration of the new Hungarian Code on Civil Procedure while also exploring some other related issues. Electronic communication in administrative and judicial matters was fostered by the European Union in order to develop e-government in member states. The first part of the study explores the EU's policy on e-government which served as a framework for the member states to implement. The second part aims at giving an overview of the e-government initiatives in Hungary. It can be seen that there were several initiatives for advancing the development of e-government in the past, however they only came into fruition recently when the new code on civil procedure and the new act on administrative procedure were adopted. The last two parts of the paper give an overview of the aforementioned acts. It can be concluded that the legal profession is not quite ready for these changes.

Keywords: $\quad$ e-government, civil procedure, Hungary, Digital Agenda

\section{INTRODUCTION}

Act CCXXII of 2015 on the General Rules of Electronic Administration and Trust Services (E-Administration Act) obliges business entities and attorneys, legal representatives to communicate with official bodies and authorities (e.g.: local government, courts, arbitration courts, the Prosecutor's Office, public notaries) through electronic administration since the 1st of January 2018. The Act refers to these authorities as "organizations that provide e-administration" but in this thesis I will refer to them simply as authorities. The principle of the e-administration is the opportunity for an authority to get in touch with the client safely using electronic services. This is the so-called "official availability/registered contact point/safe delivery service address".

Pál Emil Mészáros, PhD, Department of Criminal Law and Litigation, Faculty of Law, University of Pécs, H-7622 Pécs, 48-as tér 1., Hungary. Email address: meszaros.pal@ajk.pte.hu. ORCID: https://orcid.org/0000-0002-7139-3089. 
The biggest change since January is that if a document is properly addressed and delivered, it is presumed to be received by the person whom it was addressed via electronic administration (the presumption of delivery). Documents sent by the authorities to the registered contact point is presumed to be delivered 5 working days after the second notice sent to the addressee (Act CCXXII Article 14.§ section (4)).

Not every e-mail address is acceptable, the registered contact point of electronic communication must be a secured/safe one. Not one service provider could have offered a safe delivery service address until the "Business gate". Official bodies and authorities, i.e. companies can send and receive documents online in official matters, but it can also be used safely as a delivery contact, and as a platform for electronic communication. Official documents received on this contact point will be provided with certification, the same way as at the "Proceedings gate" or "Governmental portal/Client gate".

The provisions of the Act define precisely which organizations are required to administer all their affairs by electronic means before authorities and enable official communication to the „sender”. The provisions of Government Decree No. 451/2016. (XII.19) regulates the detailed rules of electronic administration, and how the person entitled to the representation of the business organization shall be entitled to initialize the Business-gate registration on behalf and in the name of the business organization.

In my point of view it is significant that we analyze how the mandatory business-gate registration from the 1st of January 2018 affects courts, local government, law companies, attorneys etc., to decide whether it is a viable idea, what kind of effect it has on civil procedure, furthermore on maintaining the relationship with authorities in non-adversarial procedures. Before the examination of the legal regulations in effect and the everyday use of electronic communication it is important to review the history of information technology shortly to understand the development of information forwarding, storage and processing.

In general, the majority of people think that information technology/computer science was discovered in the 20th century, even though it goes way back in time because forwarding and processing information was always a major factor in the history of mankind. A database that registered the purchasing of slaves and land leases could be found from the time of Hammurabi already.

The development of IT devices - i.e the computer, that is essential in electronic communication, nowadays varies from the simplest calculators to the most complexed electronic and automatic computer devices. ${ }^{1}$ Multiple successful experiments started in the 17th century to build a mechanical calculator and the name of Farkas Kempelen and his voice synthesizer should be highlighted, that was able to pronounce simpler words and syllables. To continue the line chronologically Ányos Jedlik and his drawing machine must be enhanced. The first digital electronic machine was built in 1946 with the expertise of János Neumann. ${ }^{2}$

Usage of "Computers" as János Neumann called them risen radically from the 1980s. Often compared to the significance of industrial revolution this period of time is legitimately called "the electronic revolution".

1 Christián, L., Az információs társadalom jogi vetületei, Pázmány Press, Budapest, 2013, p. 15.

$2 \quad$ Ibid. p. 16. 
Innovation like this brings up problems that can not be ignored by social sciences, such as the science of law. ${ }^{3}$ Research and explore problematic issues caused by these changes can be answered by law. Information technology law, e-justice and other special fields of law are all searching for a solution regarding IT related questions. Not to mention they also have an effect on criminal law, civil law, administrative law, nevertheless on civil procedure law as the application of law by using the internet and IT devices has altered and varied a lot. ${ }^{4}$

Electronic administration allows in administrative procedures to store personal data protected by PC security, and in the field of company law is now possible to hold Quotaholder's Meeting, the general assembly or general meeting through electronic communication services - whether be voice, data, sound or picture.

In the course of legal investigation of the Business gate, Proceedings gate and Governmental portal we cannot ignore to describe the development of e-administration in Europe and in Hungary, to detail the most important case types and in general the regulation of electronic administration in Hungary, since these fields overlap each other both in the everyday life and through legislation.

\section{EU POLICY ON E-GOVERNMENT}

E-government as a new beginning of digital communication between local government and other authorities was forced by the technological development owing to the economic improvement that provided them to use modern technologies in administrative procedures. In our sped-up world people have a rightful expectation to a well-functioning, fast and reliable administration established by the government. Most people use their computers, smartphones or other IT devices when it comes to transferring money, online shopping or communicating with each other, because it is undeniably convenient for everyone. To measure up to this level of expectations, building up an adequate IT background is just as important as the work of administrators with the required qualifications that meet the demands of the 21st century.

"The Information Society is becoming a reality. Its development is fuelled by the rapid technological change which is transforming the information industries. The nature and speed of this transformation may pose new challenges to policy-makers." In 1993 the so-called „White Paper" was issued by the Commission that summarized the key elements - claims, plans and answers - triggered by the impact of technology on the economic sector. The Bangemann Report was to devise concrete projects around the ideas proposed in the White Paper. ${ }^{6}$ This report pointed out that the United States and Japan are further ahead on creating an Infor-

3 Balogh, Zs. Gy., Jogi Informatika, Dialóg Campus Kiadó, Budapest-Pécs, 1998, pp. 160-163.

4 Pázmándi, K., Verebics J., E-Jog, HVG-ORAC, Budapest, 2012, pp. 16-23.

5 Green Paper on the convergence of the telecommunications, media and information technology sectors, and the implications for Regulation - Towards an information society approach, COM/97/0623 final, 1997. december 3., Introduction. 
mation Society, the benefit of it will only appear in these countries, therefore a rapid action is required on behalf of the EU.?

The Bangemann report was to devise an eEurope action plan in order to bring into effect a society, based on information and technology overall in the EU. In March 2000 a document with ten action programmes named "eEurope 2002" was developed and then approved by the prime ministers and the head of government of the member states. For those countries that were still in the progress of accession negotiations, the eEurope+ action plan was to follow, that adopted the main objectives from "eEurope2002" taken the country-specific economic and social relations in consideration. ${ }^{8}$

Subsequently, the following action programmes were laid down in eEurope2005:

- broadband access for authorities

- public procurement procedure in an electronic way

- providing e-administration for the community.

Following these initiatives "i2010 - A European Information Society for growth and employment" strategy was adopted. It is a key component of the EU's renewed "Lisbon" competitiveness strategy and it is strongly focused on growth and employment. During the spring session, the European Council agreed with the statement that knowledge, research and innovation are driving forces of sustainable development and promoted full compliance on building a fully inclusive information society, based on widespread use of information and communication technologies in administration, small- and medium-sized enterprises and also in households. ${ }^{9}$

The European Commision, based on the earlier programmes and challenges and with the related consultations and expert reports, suggested three priorities for the European Union and its policy:

achieve a single European information space that promotes an open and competitive internal market in the area of information society and media

investing in ICTs and innovation, that "delivers stronger and lasting growth and creates more and better jobs"

an information society for all without social exclusions, which is a significant source of employment and growth, and meets with the requirements of sustainable development with the emphasis on better public services and quality. ${ }^{10}$

The aim was to improve living conditions and the quality of life for all citizens throughout the European Union with accessible and cost-effective public utilities. The purpose of the Europe's Digital Agenda 2010-2020 is that citizens can all enjoy the benefits of the digital era and that it became the engine for economic growth in the EU, nevertheless to improve people's living standards. ${ }^{11}$

7 Torma, A., Az információ jelentôsége a (köz)igazgatásban, Virtuóz, Budapest, 2002, pp. 178-179.

8 Christián, op. cit. note 1, pp. 272-274.

9 http://infoter.eu/alapdokumentumok/i2010-europai-informacios-tarsadalom-a-novekedesert-es-a-foglalkoztatas ert.

10 European Commission, „i2010 - A European Information Society for growth and employment” COM(2005) 229.

11 http://infoter.eu/alapdokumentumok/europai-digitalis-menetrend. 


\section{E-GOVERNMENT IN HUNGARY}

E-government (short for electronic government) generally means that a network-based technology is used for communication and to serve the interests of the general public. Electronic procedures, e-administration and developing infrastructure are a government responsibility. ${ }^{12}$ In addition, the government is supposed to ensure legislation that helps to build and develop a Hungarian information society. We shall differentiate between two periods in this view. The period before the change of regime, where there was no chance for an information society to build up, and the period after, where the conditions were laid down by the EU and the rapidity, that forced the Hungarian legislation an almost word-for-word implementation of EU directives. ${ }^{13}$

Government and civil attempts are both have the interest of developing an information society. Governmental strategies were, for example, the "Digital Hungary Programme", "Action Plan on a Digital Hungary" or the "National Strategy on Infocommunication". As a conclusion, we can notice that there was no sufficient time to achieve the objectives they were aiming for. Unfortunately, this problem appears in other member states too, and the frequent change of action plans established by the EU makes it even more complicated. ${ }^{14}$

The electonic administration has three-course lines: the development of the infrastructure, establishing an institutional framework and the initiation of services. Governmental organizations and the Government Commissioner of Information Technologies were appointed to support the development of e-administration. ${ }^{15}$ The essential of e-government and administration, the system of the central electronic service provider was set up at that time too. ${ }^{16}$

General regulations on digital services were enacted by the Act CVIII of 2001 on certain issues of electronic commerce services and information society services. The Act had no effect on court proceedings and court cases, but it had a great impact on the outlook of electronic administration. The Act XXXV of 2001 on Electronic Signature was adopted by the Hungarian Parliament around that time too. ${ }^{17}$

A change of approach shows itself in the Act CXL of 2004 on the General Rules of Administrative Proceedings and Services. Although the Act has no specific regulations on e-administration, its importance shows that it was the first time it was mentioned and defined by law. The opportunity of electronic communication was given, as the principals were laid down in Act CXL of 2004 on the General Rules of Administrative Proceedings and Services, but in re-

12 Budai, B. B., E-government avagy kormányzati és önkormányzati kihívások az on-line demokrácia korában, Aula Kiadó, Budapest, 2002, p. 129.

13 Czékmann, Zs., Információs társadalom és elektronikus kormányzat Magyarországon, Miskolc, 2016, pp. 44-47.

14 Ibid.pp. 44-47.

15 Government Resolution No. 1039/1993. (V. 21.) on the Coordination of the Development of the IT Infrastructure of Central Governmental Bodies, Government Resolution No. 1066/1999. (VI.11.) and Government Resolution No. 1106/1995. (IX.9.) on the Further Development of Administrative IT Systems. Government Resolution No. 1188/2002. (XI.7.) on the Electronic Governmental Backbone Network and the Public IT Network.

17 Csáki-Hatalovics, Gy. B., Grad-Gyenge, A., Ludányi, A., Udvary, S., Infokommunikációs jog I., Patrocinium Kft, Budapest, 2014, p. 159. 
ality, the system of e-administration was introduced to users by the detailed rules enacted by the government. ${ }^{18}$

Multiple attempts between 2001 and 2006 aimed at the establishment of e-administration, but considering that it had no centralised model, only created chaos and confusion. However electronic services and its regulations for tax declaration were frontrunners in e-administration, its innovation affected the entire procedure of electronic administration. The National Tax and Customs Administration of Hungary (APEH/NAV) developed the so-called „eBEV2006” which still serves as the basis of Framework Form Filling Programme (ÁNYK). ${ }^{19}$

There were, in fact, other failed initiatives, for example, the electronic procurement procedure which was introduced in 2003, therefore it took ten years to establish a stable procedural system.

The electronic portal, so-called "Client Gate" needs to be emphasized as being the only device that provides individually identified and secured electronic connection and e-administration with the authorities through the central system. In April 2005 before the Administrative Procedure Act entered into force, for the first time citizens could submit their income declarations electronically. National legislation for taxpayers who choose electronic administration was the Regulation 13/2005. (III.30) PM-IHM-MeHVM on the obligations to disclose information and reporting taxes to the National Tax and Financial Control Administration. ${ }^{20}$

Accordingly to "COM/2001/0140.final" published by the European Commision, in Hungary the government decree 1044/2005. (V.11) defined four stages regarding the electronic administration. Another legal instrument was the "Common List of Basic Public Services" launched by the EU, specifying altogether twenty priority areas that shall be made available in an electronic way. ${ }^{21}$ Not twenty but twenty-seven areas were formed by the Hungarian legislation, that being the case because the service sectors codified by the European Union differ from the ones in Hungary. ${ }^{22}$

A crucial step on the way of electronic administration was the introduction of the "Business gate/company gate" and it's importance in Hungarian legislation, because for the first time an entire procedure was digitalized. The reason it should be highlighted is, that it was implemented by a rather conservative court system. Directive 2003/58/EC of the European Parliament and of the Council amending Council Directive 68/151/EEC, as regards disclosure requirements in respect of certain types of companies made a legal harmonization necessary, therefore electronic register- data processing- and data services came into effect. ${ }^{23}$ Focused on four areas we can differentiate between the following objectives:

- $\quad$ electronic business register

- $\quad$ paper-based documents modified into an electronic form

- electronic communication between the business register and the client

18 Czékmann, op. cit. note 13, p. 74.

19 Act No. 92 of 2003 on the Rules of Taxation; Decree of the Minister of Finance No. 20/2004. (IV. 21.) PM. on the Electronic Invoice.

Czékmann, op. cit. note 13, p. 75.

$21 \operatorname{COM}(2000) 330$ Final.

22 Czékmann, op. cit. note 13, p. 76. 
- $\quad$ available company information via Internet. ${ }^{24}$

The aim was to reduce administrative burdens in order to improve competitiveness and for that e-administration became extended. Act V of 2006 on Public Company Information, Company Registration and Winding-up Proceedings entered into force in July 1st, making the electronic business procedures optional from January 1st, 2007. Paper-based and electronic administration were running parallel, although there were fewer requirements and a simplified way for the ones that choose the electronic way. An amendment of the Act has put a stop to it, at which point electronic administration in business matters became obligatory.

Beyond any doubts, a rapid transition was completed in the field of electronic business proceedings. The main characteristics of these proceedings were the reason this process completed so quickly. Separated from other procedures it is a well-defined system with an administrative nature that could, if necessary, be formalised easily. Given that legal representation is mandatory in these proceedings, it only affected attorneys at law. Seemingly the whole economic sector was influenced by the new regulations, even though it was used only by highly qualified professionals. Digitalizing business proceedings turned out to be a success and competent for initiation because the basic conditions were available for establishment. Because of it's effectiveness, further administrative matters could have been managed by electronic means. Electronic communication integrated gradually to court proceedings until it was compulsory. ${ }^{25}$ Since 2012 e-administration was permitted in fact required for the registration for civil society organisations later on in the legal proceedings ${ }^{26}$ and noncontentious proceedings. ${ }^{27}$ According to the public procedural law since 1. January 2016 a broad range of business entities and authorities will be obliged to carry out an expansive list of administrative procedures by means of electronic communication.

The EU's action to build up the European Information Society is no more optional for the member states, it is obligatory. Member States shall bring into force the laws, regulations and administrative provisions necessary to comply with the Directive 2006/123/EC of the European Parliament and of the Council on services in the internal market. The result of this is the Act No. LX. 2009 on Electronic Public Services, where the legal harmonization was fulfilled by the Hungarian legislation. Due to government transition, the act was repealed in 2010, so it has never been put into practice. Recodifications started later in 2011 while the functioning of the general regulations of administrative proceedings was also reviewed in the framework of the Magyary Programme. ${ }^{28}$

Act No. CLXXIV. 2011 regulated the provisions of electronic administration in Chapter No. X. Act No. CXL. 2004, repealing Act No. LX. 2009 at the same time. Paper-based communication and e-administration became equal with the difference of the cost-effectiveness of the electronic way. ${ }^{29}$ Regulated and provided by the government a system for the electronic

\footnotetext{
24 Directive 2003/58/EEC.

25 Czékmann, op. cit. note 13, p. 79.

26 Act No. 3 of 1952 on on the Code of Civil Procedure Chapter XXVIII.

27 Act 50 of 2009 on the Order for Payment Procedure.

28 Czékmann, op. cit. note 13, p. 83. 
services was established. This means services, that are necessary for the basic functioning of e-government. The so-called SZEÜSZ-system aims for an integrated and coordinated administration procedure. ${ }^{30}$

The Act on the electronic administration not being in effect was problematic, concerning the governmental gate. In fact, this Act included the regulations on the governmental portal and therefore the legal framework had no basis at all, the governmental gate was de iure terminated. Legislation on that matter was missing on the contrary that de facto it was still functioning, not to mention, it was a relevant matter in electronic communication. ${ }^{31}$

Act CCXXII of 2015 on the General rules for the electronic administration and trust services entered into force on 1 January 2016 and its provisions of which will among others replace the provisions of Act XXXV of 2011 on Electronic signatures. ${ }^{32}$ The new legislation was enacted by the Parliament essentially in furtherance of widespread extension of electronic administration services, accelerated procedures and declining administrative burdens, wider computerisation of various legal relationships as well as the provision of more streamlined and efficient public services for the general public. The Act is partly based on Regulation 910/2014/EU under its abbreviated name: eIDAS („electronic identification and trust services") Regulation. ${ }^{33}$ As from January 2017, economic organisations and legal representatives will be required to administer all their affairs by electronic means in court, or before other authorities (or even public utility providers). Natural persons may only be obligated by legislation to administer their affairs by electronic means; therefore, paper-based administration in person is still available for individuals. Given that the Act has only general provisions on electronic administration further refining and enacting detailed rules are necessary. Hungarian legislation complied with its obligation by Governmental Decree 451/2016 (XII.19.) on the rules of electronic administration.

Problematic issues arose concerning the Business gate, because organizations, business entities have not registered in time, therefore they failed to fulfil provisions of the legislation. Approximately half of the companies have not obeyed the law. and such news spread in December 2017 that communication through the business gate will not yet be mandatory until 31. December 2018. ${ }^{34}$ This statement contradicts the press release by the Ministry of Interior of which registering to the Business gate is obligatory, Government gate can only be used until 31. December 2018 and only in relation to taxation matters. ${ }^{35}$ Business gate and Governmental gate provide similar electronic services which means they cannot be interpreted and examined separately. E-Litigation Portal was used for communication between legal representatives and the court to forwarding and receiving documents. Law offices, law firms must register into the Business gate, on the other hand, individual attorneys, lawyers are still allowed to use Governmental portal concerning their official affairs.

\footnotetext{
30 Péterfalvi, N.; Budai, B. B.; Rátai, B.; Ligeti, Á.; Erdei, Cs., Az elektronikus közigazgatás alapjai - szabályozott elektronikus ügyintézési szolgáltatások - IT biztonság, Nemzeti Közszolgálati Egyetem, Budapest, 2014.

31 Czékmann, op. cit. note 13, p. 87.

32 http://www.krs.hu/sites/default/files/tudastar/elektronikus-ugyintezes.pdf.

33 http://eur-lex.europa.eu/legal-content/HU/TXT/PDF/?uri=CELEX:32014R0910\&from=HU.

34 http://www.origo.hu/jog/lakossagi/20171227-origo-jog-januartol-meg-nem-kotelezo-cegkapu.html. 


\subsection{ELECTRONIC ADMINISTRATION IN PUBLIC PROCEEDINGS AND NON- CONTENTIOUS PROCEEDINGS}

Electronic services are becoming extended, a certified hosting place that provides registered electronic delivery address is available since the 28th of October 2017. This improvement enables an integrated platform for those who have registered to Governmental portal and Business gate. Under the provisions of government decree 451/2016 (XII.19.) on the detailed rules on electronic administration the Company gate will serve as a secure electronic delivery address which will be granted to the business entities by a service provider appointed by the Hungarian government. ${ }^{36}$ All business entities are entitled to have Business Gate with an authorized person as a representative.

Act CCXXII. 2015 refers to business organizations/business entities as "a business entity located in Hungary defined by the Hungarian Civil Procedure Code and does not constitute as a housing cooperative, civil association or foundation". ${ }^{37}$ Individual lawyers and patent lawyers are authorized to benefit from the services of the business gate but the provisions are not mandatory for them. ${ }^{38}$

Through Business gate organizations have an online connection with authorities and other services that provide e-administration. Without any personal appearance documents can be sent and received a lot faster and in a more cost-effective way. Under the provisions of Act CCXXII. 2015 on the General Rules of Electronic Administration and Trust Services business entities are obliged to register their contact details for electronic communication (official contact point). Services with electronic contact point are listed by the Act mentioned above. On contrary Client gate is the official central electronic administration web service of the country maintained by the Hungarian government. ${ }^{39}$ It is an electronic system that provides identified and secured entering the Client gate and so enables the communication with authorities and other organizations through e-administration.

Company gate is also noted as another contact point regarding electronic administration. It's importance shows by the obligatory character, in fact, that business organizations and other clients - obliged by law - must register and communicate through Company gate.

Legislation regarding e-administration and civil procedures was ensured by the Civil Procedure Code and by the Act No. CLXXX. 2015 on amending procedural and judicial laws, in which the aim was to accelerate the procedure in court proceedings by communicating through online services. Provisions regulated by the law came into effect on the 1st of January 2016 although in civil proceedings was only applicable since the 1 st of July $2016 .{ }^{40}$

Since lawyers, legal representatives, law offices, patent lawyers, the Prosecutor's office and the court itself communicate via Business gate (and Client gate), the general provisions will be detailed hereinafter.

\footnotetext{
36 Government Decree 451/2016 (XII.19.) on the Special Rules of Electronic Administration section 89.

37 Act 222 of 2015 on the General Rules for Trust Services and Electronic Transactions section 1. point 23.

38 Government Decree 451/2016 (XII.19.) on the Special Rules of Electronic Administration section 91.

39 http://adozona.hu/2017-es-valtozasok/cegkapu-8WIY5M. 


\subsection{ELECTRONIC ADMINISTRATION IN COURT PROCEEDINGS}

Justification and interpretation of the Hungarian Civil Procedure Code points out, that the regulations enacted by the act are only applicable during court proceedings. The electronic administration just as other fields of law related to information technology (e.g. ITlaw) alters easily, changes has to be made frequently given certain life situations, revision, amendment and repeal is often necessary just as establishing new legislation. Civil Procedure Code was made to be long-lasting and effectively functioning, detailed regulations need to initiated by further enactment. Hungarian legislation fulfilled this requirement since - as I mentioned before - Civil Procedure Code only regulates special proceedings compared to the E-administration Act.

Electronic communication is available since the 1st of January 2013 in regional court proceedings in fact since the 1st of January 2015 during judicial proceedings in general, although only a few lawyers did not miss this opportunity. ${ }^{41}$ E-administration was pre-judged as an unsafe and complicated service, therefore not knowing its application made legal experts abstaining from using it as a communication tool. From my point of view, these fears were gratuitous assumptions, after all, submitting documents with e-signatures is fast and convenient and does not let unauthorized third persons modify or delete these documents.

Electronic and paper-based administration existing parallel considering the fact that not everyone is obliged to administer their official affair by electronic means. This kind of dualism will last - as I take, rightfully - until legislation decides otherwise or E-administration Act orders all individuals to create a Client portal on their own, though it would violate greatly the principle of private autonomy. No one shall suffer prejudice refusing to communicate through electronic services. In my opinion, the principle of the right to apply to the courts would be violated and jeopardized by introducing such legislation.

In accordance with previous regulations, since online communication is only mandatory for business entities, one shall decide whether to contact the court through e-administration or the traditional paper-based way. Civil Procedure Code does not regulate special procedural provisions regarding electronic communication, general rules specified by the Act are applicable taking the exceptional rules by the E-administration Act into consideration. It is important to point out that besides the Civil Procedure Code, E-administration Act and its Implementing Regulations must be applied to electronic procedures as well.

If one decides to communicate by electronic means at any stage in the procedure - despite it was not mandatory for them - simply submitting the document electronically is the only requirement. The court presumes based on submissions like that, that the party choose to communicate hereinafter electronically. Such a decision must be made reasonably because switching back to paper-based procedure is only possible on special request with the court's permission and only in legitimate cases. In order to protect the court from the consequences of a long-drawn-out procedure and to spare the additional costs, the procedural system cannot be changed whenever the party wants to do so. Once e-administration was chosen by the party, his documents have legal effect only when they were submitted electronically. We 
can refer to it as a miscellaneous procedure when one party chose to communicate by paper, the other communicates electronically with the court. In this scenario, electronic documents received by the court will be delivered on paper to the party who preferred the paper-based way, until paper-based documents will be digitalized by the court and sent to the other party electronically. ${ }^{42}$

When the party or the person authorized as a representative undertake to interact with the court by electronic means, but later they become incapable of electronic communication due to an unforeseeable circumstance, paper-based administration can be permitted by the court on request. The reason for the change must be made likely and has to stand on solid ground assuming the fact that it would cause disproportional exertion to them. Only in case of refusal, a court decision has to be made. Even though the court rejected the party's request switching to paper-based administration, the documents submitted on paper still have the legal effect and will be taken into consideration. The party has the right to appeal which can be presented in a paper-based document. Submitting a groundless request again with other documents attached, the court will not take it into account and will be considered as an invalid submission. This is justified, because if the request has no legal basis, the party shall not be able to have a legally valid declaration. The representative may even be obliged to pay a fine based on his obviously inappropriate petition. ${ }^{43}$

Legal succession may have an effection on the communication considering that the legal successor might not be obliged to electronic administration. Even if the predecessor and the court contacted with each other online, the legal successor has the right to choose paper-based administration. Regardless of whether the predecessor requested a paper-based communication before, the legal successor is authorized to submit such a request as well. ${ }^{44}$

Persons entitled to electronic administration are listed under the paragraph 608.§ of the Civil Procedure Code. This paragraph refers to E-administration Act where the procedure of electronic administration and the persons obliged for electronic communication are specified. Under the provisions of the Act e-administration is mandatory for the following: business associations, the state, the local government, budgetary authority, the prosecutor, the notary, public bodies, administrative bodies and the legal representative. In civil procedures, the party is mostly a natural person, a business organization or a legal representative thus my thesis is focused mainly on them. The definition of business entities is laid down in E-administration Act by referring to the terminology of the Civil Procedure Code with the exception of declaring organizations without legal personality with locally registered office as business associations. Those are the following: business associations, european company, associations, european economic interest groups, european grouping for territorial cooperations, cooperative societies, housing cooperatives, european cooperative society, water management association, associations of forest holders, branch office of foreign company, public companies, other public bodies, corporations with legal personality, joint company, executive offices, notary's office, law offices, patent agent offices, mutual-type associations, private pension offices, the individual

42 Wopera, Zs., A polgári perrendtartásról szóló 2016. évi CXXX. törvény magyarázata, Wolters Kluwer Kft, Budapest, 2017, pp. 936937.

43 Ibid. pp. 937-939.

44 Ibid. p. 682. 
company, individual entrepreneurs, the state in business matters, local government, organizations with legal personality with budgetary matters, associations, public bodies, foundations and other organizations required by the E-administration Act. ${ }^{45}$ Legal representatives are the lawyer, law firms, the legal counsel on matters specified in the act on attorneys at law, the judge and the court clerk authorized to representation, the General Prosecutor as a representative, the trainee lawyer and other representatives determined by law. ${ }^{46}$

\section{CONCLUDING REMARKS}

Considering the fact that Business gate and Client gate are the platforms of electronic communication between the parties and the court an official electronic mailbox, as an official contact point is necessary. Documents via this "official online mailbox" can be sent and received from the court or other authorities. Framework Form Filling Programme is still available as an assistance, attachment needs to be attached and signed by the authorized person. The system remains to be the same, but it is important to point out that the "proceedings gate" no longer exists, thanks to this innovation, documents can be submitted at the Client gate. Without a doubt, electronic communication since Client gate has developed greatly, but in my opinion, previous initiatives had not enough time to come up to its expectations. It is also not fortunate that after a year and a half the system of the communication alters, because it may cause problems for those who are unconversant at information technological matters, practised legal representatives will not take cases like this. Getting used to the previous system took some time itself, now with the new, "modern" online surface sending and receiving documents is even more complicated then it was before. As I take it, if the improvements were installed at a later date, technical problems, long-continued and discontinued proceedings would have been evitable. This is supported by the fact that evidence is often not attached properly, or are insufficient, and court proceedings will be unduly delayed. Business organizations and legal representatives are not the only ones having some trouble with the IT system, problems may occur at other authorities too, for example, the local government. In one case it took nine months to continue the proceedings because the request on a judicial review sent to the local governments' Client gate was "forgotten" and not forwarded to the court.

From my point of view e-administration is an ambitious goal, but for a project like this, creating a suitable infrastructure and environment is inevitable. Without the conditions needed, duration of the proceedings will not be shorter but actually, it will cause long-continued proceedings.

In my research, I focused on presenting and methodizing the regulations of electronic administration none the less defining its aims. I attempted to give an overall view of its development and legislation since e-government and e-administration as a type of electronic communication regulate the proceedings by electronic means.

45 Act 130 of 2016 on the Code of Civil Procedure section 7 point 6.

46 Act 130 of 2016 on the Code of Civil Procedure section 75 paragraph 1 and Act 130 of 2016 on the Code of Civil Procedure section 608 paragraph 2. 
Regulations and provisions just as well the IT background is detailed in my thesis. I pointed out before and I am convinced, e-administration is welcomed, but much more needs to be done to achieve success. Information technology and its relations with the public is fragile and that shows in electronic proceedings as well. Although seniors have a lot of experience, they may not be able to use their skills because they don't have the daily routine with computers like a young person, who adjust to new things easily. This could lead to a predicament, such as experienced lawyers will not accept assignments, and this way freshly graduated lawyers will represent the party during civil proceedings. A possible solution could be organizing further training and providing assistance on a regular basis, so the knowledge they could pass on to the younger generation won't vanish into thin air.

\section{REFERENCES}

1. Balogh, Zs. Gy., Jogi Informatika, Dialóg Campus Kiadó, Budapest-Pécs, 1998, pp. 160-163.

2. Christián, L., Az információs társadalom jogi vetületei, Pázmány Press, Budapest, 2013, p. 15.

3. Czékmann, Zs., Információs társadalom és elektronikus kormányzat Magyarországon, Miskolc, 2016, doctoral thesis.

4. Csáki, Gyula Balázs, Az elektronikus közigazgatás tartalma és gyakorlatának egyes kérdései, Pécs, 2009, doctoral thesis.

5. Csáki-Hatalovics, Gy. B.; Grad-Gyenge, A.; Ludányi, A.; Udvary, S., Infokommunikációs jog I., Patrocinium Kft, Budapest, 2014.

6. European Commission, Green Paper on the convergence of the telecommunications, media and information technology sectors, and the implications for Regulation - Towards an information society approach, COM/97/0623 final, 1997. december 3.

7. European Commission, i2010 - A European Information Society for growth and employment $\operatorname{COM}(2005) 229$.

8. Pázmándi, K., Verebics, J., E-Jog, 2012., Budapest, HVG-ORAC, pp. 16-23.

9. Péterfalvi, N.; Budai, B. B.; Rátai, B.; Ligeti, Á.; Erdei, Cs., Az elektronikus közigazgatás alapjai, szabályozott elektronikus ügyintézési szolgáltatások, IT biztonság Nemzeti Közszolgálati Egyetem, Budapest, 2014.

10. Torma, A., Az információ jelentősége a (köz)igazgatásban, Virtuóz, Budapest, 2002.

11. Wopera, Z., A polgári perrendtartásról szóló 2016. évi CXXX. törvény magyarázata, Wolters Kluwer Kft, Budapest, 2017.

\section{LIST OF REGULATIONS AND ACTS}

1. Act 130 of 2016 on the Code of Civil Procedure.

2. Act 140 of 2004 on on the General Rules of Administrative Proceedings and Services.

3. Act 222 of 2015 on the General Rules for Trust Services and Electronic Transactions.

4. Act 50 of 2009 on the Order for Payment Procedure. 
5. Act No. 3 of 1952 on on the Code of Civil Procedure.

6. Act No. 92 of 2003 on the Rules of Taxation.

7. Decree of the Minister of Finance No. 20/2004. (IV. 21.) PM. on Electronic Invoice.

8. Directive 2003/58/EEC.

9. Government Decree 451/2016 (XII.19.) on the Special Rules of Electronic Administration.

10. Government Resolution No. 1039/1993. (V. 21.) on the Coordination of the Development of the IT Infrastructure of Central Governmental Bodies.

11. Government Resolution No. 1066/1999. (VI.11.) on the Further Development of Administrative IT Systems.

12. Government Resolution No. 1106/1995. (IX.9.) on the Further Development of Administrative IT Systems.

13. Government Resolution No. 1188/2002. (XI.7.) on the Electronic Governmental Backbone Network and the Public IT Network.

\section{WEBSITE REFERENCES}

1. http://www.krs.hu/sites/default/files/tudastar/elektronikus-ugyintezes.pdf.

2. http://eur-lex.europa.eu/legal-content/HU/TXT/PDF/?uri=CELEX:32014 R0910\&from=HU.

3. http://www.origo.hu/jog/lakossagi/20171227-origo-jog-januartol-meg-nem-kotelezo-cegkapu. html.

4. http://www.jogiforum.hu/hirek/38630

5. http://adozona.hu/2017-s-valtozasok/cegkapu.8WIY5M.

6. https://www.kompkonzult.hu/adovilag/az-elektronikus-kapcsolattartas-szabalyai-egyes-birosagi-eljarasokban. 
Pál Emil Mészáros*

\section{RAZVOJ ELEKTRONIČKE UPRAVE I NJEZINA PRAKTIČNA PRIMJENA U SUDSKOM POSTUPKU}

\section{Sažetak}

Cilj rada je ispitati odredbe koje se odnose na elektroničku upravu u novom mađarskom Zakonu o građanskom postupku, te istodobno istražiti i neka druga srodna pitanja. Elektroničku komunikaciju u upravnim i pravosudnim pitanjima potiče se u Europskoj uniji kako bi se razvile e-vlade u državama članicama. Prvi dio rada istražuje politiku EU-a vezano uz e-vladu, a koja predstavlja okvir za provedbu u državama članicama. Cilj je drugog dijela rada dati pregled inicijativa vezanih uz e-vladu u Mađarskoj. Vidljivo je da je u prošlosti postojalo nekoliko inicijativa za unaprjeđenje razvoja e-vlade koje su ostvarene tek nedavno kada je usvojen novi Zakon o građanskom postupku i novi Zakon o upravnom postupku. U posljednja dva dijela rada daje se pregled navedenih zakona. Može se zaključiti da pravna struka nije sasvim spremna za navedene promjene.

Ključne riječi: $\quad$ e-vlada, građanski postupak, Mađarska, digitalna agenda

\section{(c) (1) $(9$}

This work is licensed under a Creative Commons

Attribution-NonCommercial 4.0 International License.

Dr. sc. Pál Emil Mészáros, Katedra za kazneno i kazneno procesno pravo, Pravni fakultet, Sveučilište u Pečuhu, H-7622 Pečuh, 48-as tér 1., Republika Mađarska. Adresa e-pošte: meszaros.pal@ajk.pte.hu. ORCID: https://orcid.org/0000-0002-7139-3089. 